\title{
Spatial modeling of forest fires in Mexico: an integration of two data sources
}

\author{
Modelación espacial de incendios forestales en México: una integración de dos bases de datos
}

\author{
José Manuel Zúñiga-Vásquez a, Darío Cisneros-González a, Marín Pompa-García a*, \\ Dante Arturo Rodríguez-Trejo ${ }^{b}$, Gustavo Pérez-Verdín ${ }^{\mathrm{c}}$ \\ *Corresponding author: a Universidad Juárez del Estado de Durango, Facultad de Ciencias Forestales, \\ Rio Papaloapan, Valle del Sur, 34120 Durango, México, mpgarcía@ujed.mx \\ b Universidad Autónoma Chapingo, División de Ciencias Forestales, km 38,5 Carretera México-Texcoco, \\ Chapingo Estado de México, México, dantearturo@yahoo.com \\ c Instituto Politécnico Nacional, CIIDIR Durango, Sigma 119, Fracc. 20 nov. II. Durango, México, guperezv@ipn.mx
}

\begin{abstract}
SUMMARY
Forest fires are a cause of global concern, which requires generating knowledge on their spatial behavior. By hypothesizing that the spatial pattern of forest fires across Mexico is randomly distributed, this study aimed at making an analysis of the distribution of forest fires (2005-2015) using remote sensing information and field data collected by CONAFOR (National Forest Commission) and MODIS (Moderate-Resolution Imaging Spectroradiometer). The study compared both sources of information through the G-statistic test that identified clustering patterns. The "hot spots" analysis identified clustered areas with significant values in both data sources. These zones were extended through Sierra Madre Occidental, Península de Yucatán, northern Sierra Madre Oriental and Península de Baja California. The highly coincidental clusters were found in the central-western region along the Eje Neovolcánico, as well as in a small part of Sierra Madre del Sur. The analysis of spatial correlation determined that both sources of information complement each other, enhancing their scope. It is concluded that forest fires in Mexico follow a spatial clustering trend.
\end{abstract}

Key words: hotspots, cluster-patterns, spatial-correlations, G statistics.

\section{RESUMEN}

Los incendios forestales son una causa de preocupación mundial, lo que requiere generar conocimiento sobre su comportamiento espacial. Hipotetizando que el patrón espacial de los incendios forestales en México se distribuye de manera aleatoria, este estudio tuvo como objetivo analizar la distribución de los incendios forestales (2005-2015), utilizando información de sensores remotos y datos de campo recopilados por CONAFOR (Comisión Nacional Forestal) y MODIS (Espectrorradiómetro de Imágenes de Resolución Moderada). El estudio comparó ambas fuentes de información a través de la prueba del estadístico G que identificó patrones de agrupamiento. El análisis de "puntos calientes" identificó áreas de agrupación con valores significativos en ambas fuentes de datos. Estas zonas se extendieron a través de la Sierra Madre Occidental, la Península de Yucatán, el norte de la Sierra Madre Oriental y la Península de Baja California. Las agrupaciones altamente coincidentes se encontraron en la región centro-oeste a lo largo del Eje Neovolcánico, así como en una pequeña parte de la Sierra Madre del Sur. El análisis de correlación espacial determinó que ambas fuentes de información se complementaron entre sí, mejorando su alcance. Se concluyó que los incendios forestales en México siguen una tendencia espacial de agrupamiento.

Palabras clave: puntos calientes, patrones de agrupamiento, correlación espacial, estadístico G.

\section{INTRODUCTION}

Thousands of hectares of forests, savannas, grasslands, scrublands, tundra, deserts, wetlands and agricultural fields are affected by fires worldwide. Forest fires cause economic and ecological losses, specifically in Mexico (Ávila-Flores et al. 2010a). This has led to consider forest fires as a growing concern that requires knowledge of their behavior, spatial distribution and impact in order to make appropriate management decisions.
The spatial analysis is a technique that provides useful tools to assess forest fires, their causes and consequently the trends of these incidents (Díaz-Hormazábal and González 2016, Simental and Pompa 2016). Particularly, it is possible to analyze patterns of spatial distribution, allowing researchers to evaluate hypotheses on whether a phenomenon observed follows a random or correlated territorial distribution (Ávila-Flores et al. 2010a). Within the tools of the spatial analysis, the "hot spots" analysis is highlighted through the Getis-Ord G-statistic (Ord and 
Getis 1992), designed to establish and identify clustering patterns (Pompa and Hernández 2012).

In Mexico, prevention and control of forest fires are carried out by the National Forest Fire Protection Program (CONAFOR, by its Spanish acronym). Based on current regulations, CONAFOR is responsible for its instrumentation and coordination; however, data access and collection (especially on field) is sometimes complicated due to logistical and operational factors that restrict the quantity and quality of the data.

Fire prevention and suppression require solid, reliable and updated spatial tools. Worldwide, NASA -- through the Land Atmosphere Near Real-Time Capability for EOS (LANCE) -- uses Moderate Resolution Imaging Spectroradiometer (MODIS) data that provide real-time and historical data of the location of hot spots using infrared radiation. It also facilitates the capture and collection of hot spots by means of two satellites (NASA 2016). MODIS information can be easily transformed into "active fire maps"; this sensor has been used to create a global fire information management system. Since 1999, the National Commission for Knowledge and Use of Biodiversity (CONABIO) in Mexico has implemented a system for the detection of hot spots (as an indicator of possible forest fires) using daytime and night time images from an AVHRR (Advanced Very High Resolution Radiometer) sensor on board satellites of the NOAA (National Oceanic and Atmospheric Administration) sensor.

In spite of these efforts, the use of satellite tools and field data is still limited in Mexico. The use of techniques based on spatial statistics that allow improving the analysis on satellite data is little known. For instance, historical clustering trends may be helpful in defining a spatial-temporal distribution of fires on a national scale, given the biodiversity richness and biomass contributions of Mexican ecosystems (CONABIO 2016). Such ecosystems are also a source of subsistence for the population (CONAFOR 2016). The greatest challenge to establish fire regimes in Mexico might be the lack of a comprehensive and consistent national fire distribution perspective. This lack of systematized records can be complemented by spatial and temporal satellite imagery records (NASA 2016) and field data.

The objective of this study is to identify clustering trends using two data sources that combine remote sensing and field data information as an indicator of fire activity. The hypothesis is that forest fires across Mexico are randomly distributed and follow the same pattern throughout the territory.

\section{METHODS}

Study area. Mexico is located in the Northern hemisphere. To the north, it borders with the United States of America, and Guatemala and Belize to the south. The Atlantic Ocean is found on the east while the Pacific Ocean surrounds the west. The total area of the country is almost 200 million hectares and it is full of very diverse and complex ecosystems, ranging in form, location, topography and biological diversity. The territory is evenly distributed on both sides of the Tropic of Cancer, which generates completely different ecological conditions in both regions of the country for environmental and biological diversification (CONABIO 2016).

Mexico has a forest area of approximately 138 million hectares, which represents $70.4 \%$ of the territory. From 1998 to 2015 , an annual average of 8,126 forest fires occurred, with an annual affected area of 238,892 ha. Approximately $93 \%$ of this area corresponds to grassland and scrubland and $7 \%$ to adult trees (CONAFOR 2016).

Data. To analyze hot spots of forest fires in Mexico from 2005-2015, two databases were used: a) A monthly fire report provided by the National Forestry Commission of Mexico (CONAFOR) (figure 1) and b) data obtained using a Moderate Resolution Imaging Spectroradiometer (MODIS) (figure 2). The latter identifies the infrared radiation emitted by fires and their location using two satellites (Aqua and Terra).

The CONAFOR database was obtained from the Fire Management Agency (CONAFOR 2016). The information consists of the geographical location of fire points (coordinates, property, municipality, state), causes of fire, type of fire, type of ecosystem affected, area affected (ha) and duration (start and end date of the fire). Subsequently, this database was submitted to a verification and cleaning process due to possible inconsistencies. Afterwards, a shapefile of hot spots was created, which contains the previously described data.

The MODIS spectroradiometer database was obtained from the LANCE system (NASA 2016). These statistics were downloaded into a shapefile format (Esri vector data storage format) with a total of 702,991 hot spots recorded by the sensor. The data were afterward cleaned and organized for later analyses. In addition, geoprocessing was performed to segregate those spots that did not correspond to forest fires, using land cover data in Mexico (CONABIO 2016), using ArcGIS 10.0 (ESRI 2010).

Spatial analyses. The spatial analysis for the two fire databases consisted of a "hot spots analysis" based on the Getis-Ord G-statistic test (Ord and Getis 1992). This statistical tool helps identify the different clustering trends of spot densities and thus is able to verify if these fires are clustered into units with high or low values. The spatial distribution may be random, uniform or aggregate. The Getis-Ord G-statistic is used to detect the type of spatial distribution a phenomenon shows and is especially useful in cases where global traditional statistics, such as kernel estimation, k-function analysis, Moran's I index and the semi-variogram, did not display any global spatial pattern.

This analysis was performed using ArcGIS, for which it was necessary to subdivide the Mexican Republic into 852 grids using the $\mathrm{CRU}$ grid $\left(0.5^{\circ} \times 0.5^{\circ}\right)$ (UEA 2016). This is assuming that the presence of forest fires is consistent with environmental phenomena (Yang et al. 2007). 


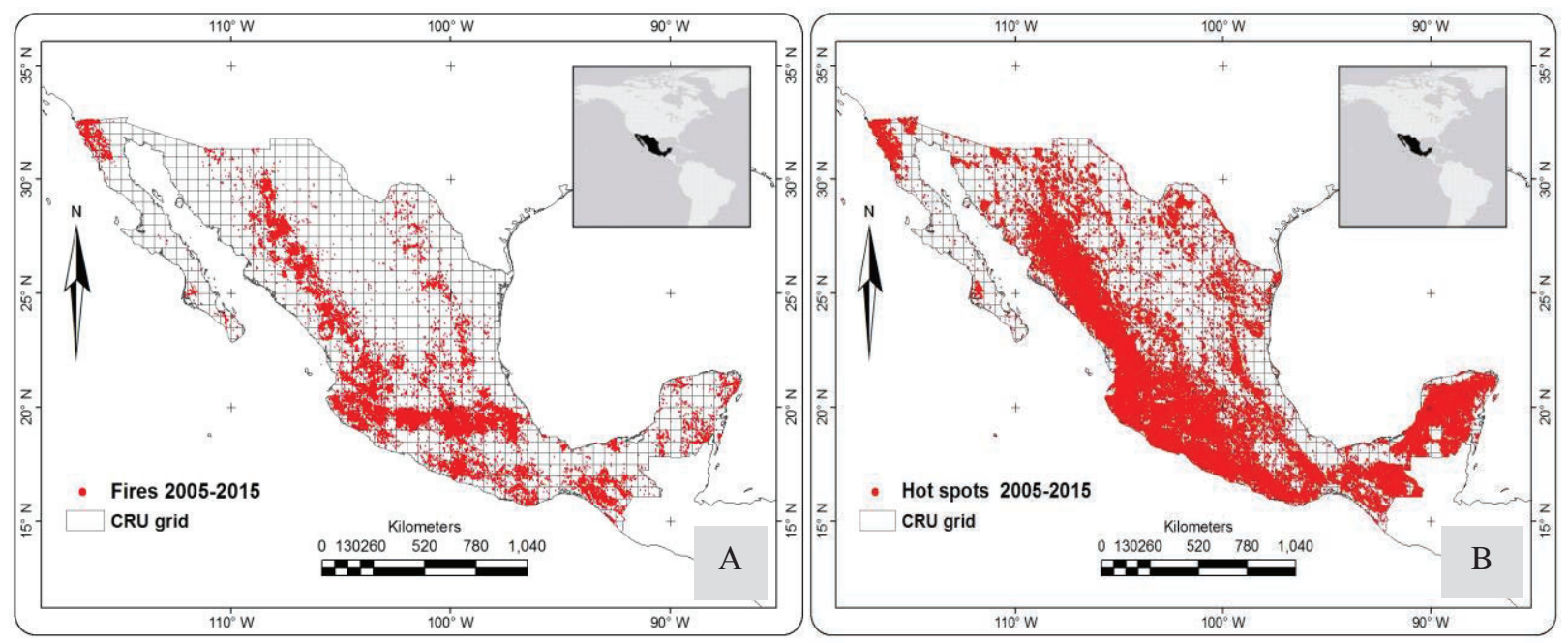

Figure 1. A) Forest fires in Mexico from 2005 to 2015, according to CONAFOR (2016). B) Hot spot in Mexico from 2005 to 2015 , according to NASA (2016).

A) Incendios forestales en México de 2005 a 2015, de acuerdo con CONAFOR (2016). B) puntos de calor en México de 2005 a 2015, de acuerdo con NASA (2016).

A spatial union was made with these grids to count the number of fires (events) in each polygon, therefore the result of this union was the analysis variable for this study.

The null hypothesis for the "Hot spot analysis" tool assumes complete spatial randomness. This analysis offers various parameters to draw conclusions (Gi Bin, $P$ value and $Z$ score value). The $Z$ score values and $P$ values indicate whether or not the null hypothesis can be rejected. Based on the above, the Gi Bin field acquires a value or a category where numbers higher than zero correspond to hot spots (aggregated distribution) and numbers lower than zero correspond to cold spots. Having small $P$ values and a very high or a very low $Z$ score value indicates that it is unlikely that the observed spatial pattern reflects the theoretical random pattern represented by its null hypothesis. Therefore, the Gi Bin field acquires a value of 0 (ESRI 2010).

In addition to that, a spatial correlation analysis (ESRI 2010) was carried out in order to generate a map of gradients on fire spatial correspondences/discrepancies in Mexico.

A spatiotemporal analysis of annual series for the two databases was carried out, to test the temporal and spatial autocorrelation in stochastic phenomena (Pérez-Verdín et al. 2013). Whether fire occurrence in a particular year was statistically related to that of the previous year was evaluated through autoregressive models (up to four lags).

Although the casual analysis of the frequency of fires is beyond the objectives of this work, an exploration of some explanatory variables is presented using Geographic Weighted Regression (Brunsdon et al. 1996, ArcGIS 10). We tested those variables used in similar studies (Ávila-Flores et al. 2010b): population density and road density from CONABIO (2016) and aerial biomass (Cartus et al. 2014).

\section{RESULTS}

In the cleaned MODIS data base, a total of 393,980 fire points were recorded. By contrast, 47,975 were reported by the National Forestry Commission of Mexico, which represent $12.17 \%$ of the former (figure 1).

As for clustering levels, hot spots, or areas with high clustering value, were found in the two databases analyzed (figures 2 and 3). The figure 2A shows the clustering values or hot spots found for the CONAFOR database, which correspond to the categories: 1 (orange color with a reliability level of $90 \%$ ), 2 (light red color with a reliability level of $95 \%$ ) and 3 (dark red color with a reliability of 99 $\%$, this one represents the category with higher fire clustering.) These categories are related to $P$ values between 0 and 0.2781 (figure 2B) and $Z$ score values from 1.4907 to 15.2887 (figure $2 \mathrm{C}$ ). In the analyses of the data of this source, there were no cold spots or low clustering spots.

The hot spot distribution described above (figure 2A) identifies the largest clustering of forest fires. These categories of clusters are distributed from east to west within the central-western region of the country, covering the area of the Eje Neovolcánico and part of Sierra Madre del Sur, which mainly have coniferous and broadleaf forest cover, as well as tropical deciduous forest (CONABIO 2016).

As for the northwestern part of the country, high clustering values were found in Sierra Madre Occidental, which has a vegetation cover of mostly coniferous and broadleaf forest. High clustering values were also found in the upper area of Peninsula of Baja California with a mediterranean shrubland cover.

On the other hand, the data of the MODIS sensor showed high clustering values or hot spots in categories 1,2 and 3 

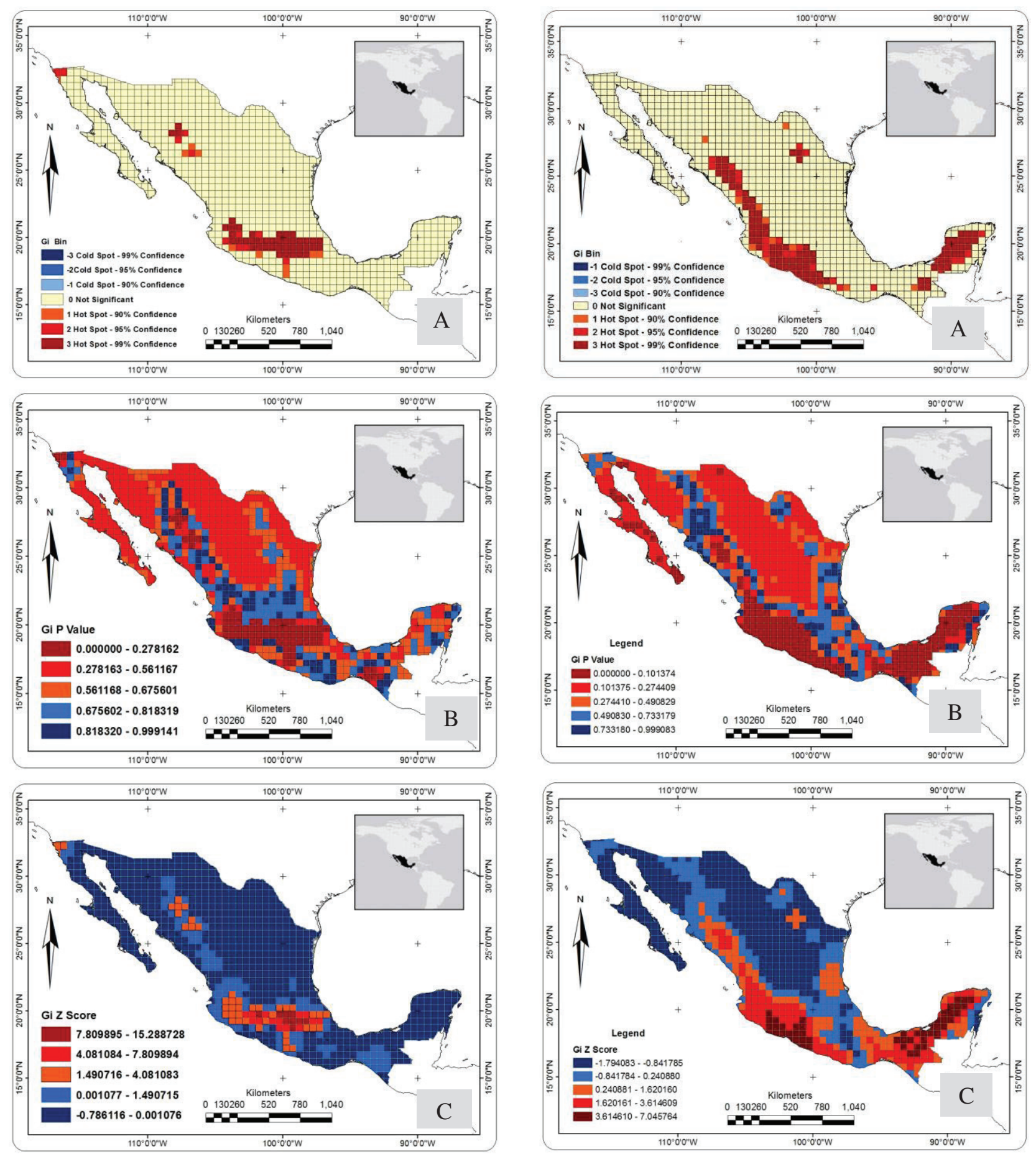

Figure 2. Forest fires according to CONAFOR 2005-2015. A) Category Gi Bin (hot spots) (estimated spatial intensity). B) $P$ values (expected level). C) $Z$ score values (standard deviation).

Incendios forestales de acuerdo a CONAFOR 2005-2015. A) categoria Gi Bin (puntos calientes) (intensidad espacial estimada). B) valores de $P$ (nivel de significancia). C) valores de puntuación $\mathrm{Z}$ (desviación estándar).

Figure 3. Forest fires according to MODIS 2005-2015. A) Category Gi Bin (hot spots) (estimated spatial intensity). B) $P$ values (expected level). C) $Z$ score values (standard deviation).

Incendios forestales de acuerdo a MODIS 2005-2015. A) categoria Gi Bin (puntos calientes) (intensidad espacial estimada). B) valores de $P$ (nivel de significancia). C) valores de puntuación $Z$ (desviación estándar). 
(figure 3A). Category 1 (orange), with a reliability level of $90 \%$ (figure $3 \mathrm{~A}$ ) shows $P$ values between 0.3123 and 0.4975 (figure 3B), which are related to $Z$ score values from 0.3257 to 1.8541 (figure 3C). Category 2 (light red) has high clustering however a reliability level of $95 \%$ (figure 3A), which corresponds to $P$ values between 0.1225 and 0.3123 (figure $3 \mathrm{~B}$ ). It is related to $Z$ scores ranging from 1.8541 to 3.8159 (figure 3C). While category 3 (dark red) has a reliability level of $99 \%$ (figure $3 \mathrm{~A}$ ) with $P$ values between 0.000 and 0.1225 (figure 3B) and $Z$ values from 3.8159 to 7.9157 (figure 3C).

The clustering categories, or hot spots as described above (figure 3A), are distributed within the northwest region along the Sierra Madre Occidental. The region, according to CONABIO (2016) has coniferous and broad-leaved forest vegetation and, to a lesser extent, tropical deciduous forests. This clustering of hot spots extends to the centralwestern region of the country, including the western end of the Eje Neovolcánico and part of Sierra Madre del Sur, where the same type of vegetation mentioned above is found. High concentrations of hot spots are also located in the southeast region, specifically in Península de Yucatán, which has mainly tropical deciduous forest, sub-deciduous forest and perennial forest vegetation.

Likewise, high concentrations of hot spots were also found in the northeast region, however in a smaller area. It specifically belongs to Sierra Madre Oriental, which is mostly covered by xerophilous scrubland.
The results obtained from the spatial correlation of hot spots of forest fires between the two analyzed data bases showed similarity/discrepancy gradients (figure 4). The disagreements of hot spots of both bases are seen in orange, while the spatial similarities between the two databases are shown in red. The lack of association in the presence of casualties is seen in white.

The temporal autocorrelation analysis found that the degree of dependence of the number of fires at a time $t$, with the same number of fires at a time $t+k$, was not significant $(P>0.05)$ for the two databases (CONAFOR: t1 $=0.055$, $\mathrm{t} 2=-0.473$, $\mathrm{t} 3=0.144$ and $\mathrm{t} 4=-0.394$; MODIS: $\mathrm{t} 1=-0.142, \mathrm{t} 2=0.072$, $\mathrm{t} 3=-0.393$ and $\mathrm{t} 4=-0.290)$. In spatial terms, the CONAFOR database (figure $5 \mathrm{~A}$ ) shows that the groups of fires follow a similar pattern year by year, generally extending through the Eje Neovolcánico, and to a lesser extent north of Sierra Madre Occidental and the upper end of Península de Baja California. Moreover, the analysis of the MODIS database (figure 5B) showed annual variability in the groups of fires, since they are distributed mainly along Sierra Madre Occidental and Península de Yucatán. This trend can be attributed to the ability of the MODIS sensor to record heat emissions, in a clear comparative advantage over CONAFOR data.

The exploratory analysis of the possible variables that influence the frequency of fires showed that the population density is significantly explanatory $\left(\mathrm{R}^{2} \approx 0.22\right.$, figure 6$)$.

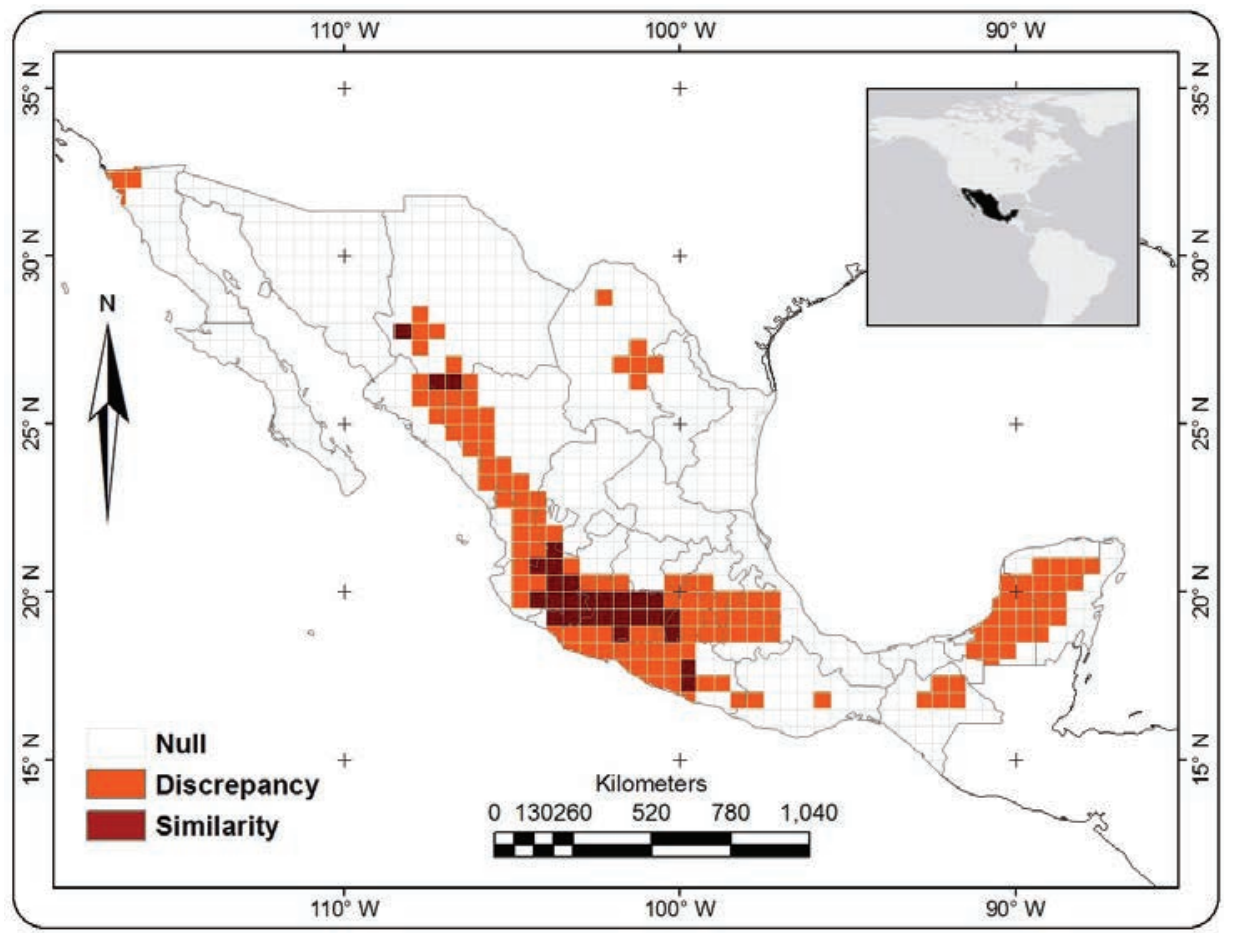

Figure 4. Results for the hot spots correlation (MODIS/CONAFOR).

Resultados de la correlación de puntos calientes (MODIS / CONAFOR). 
BOSQUE 38(3): 563-574, 2017

Spatial modeling of forest fires in Mexico

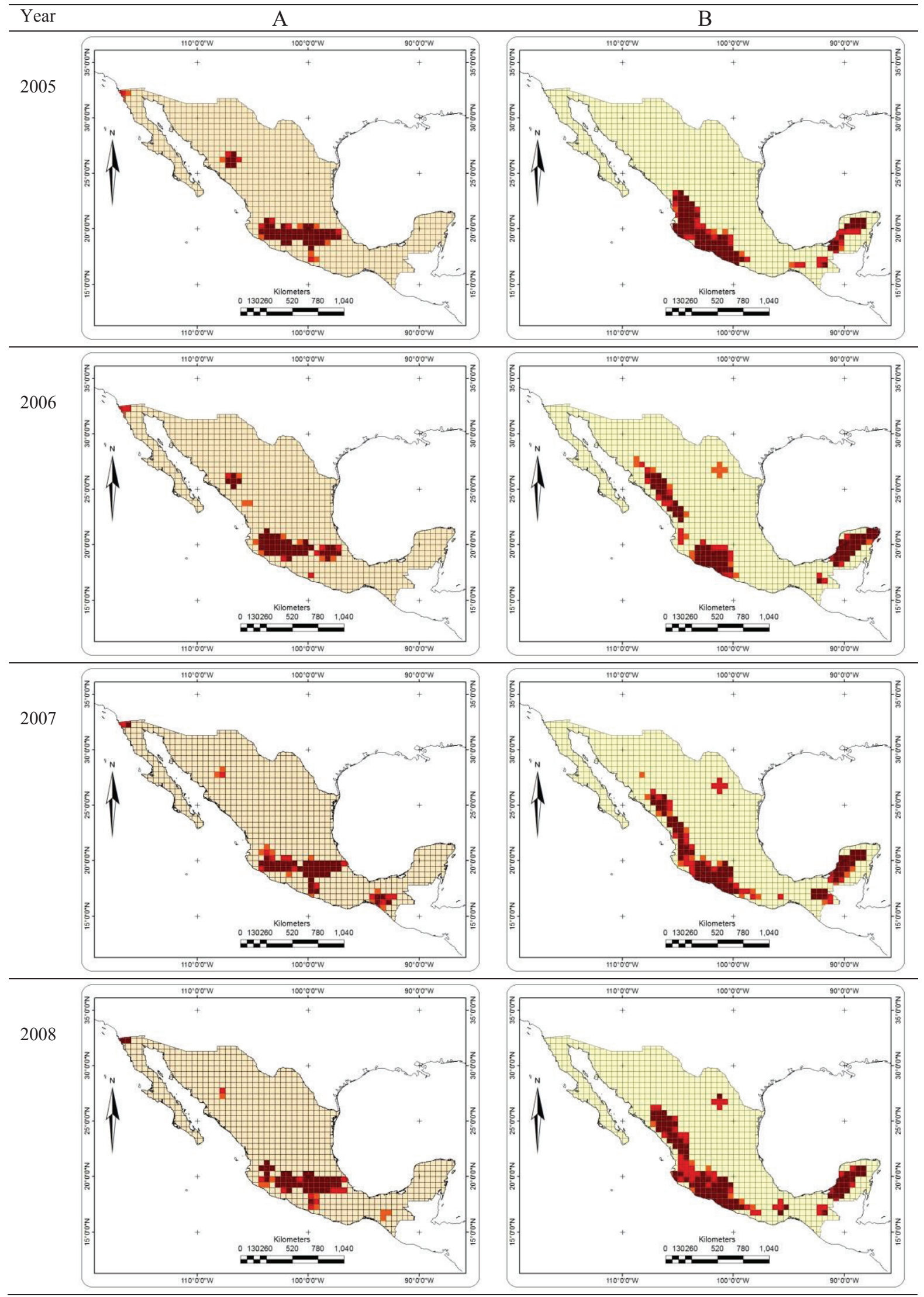

Continue 
Figure 5 Continued

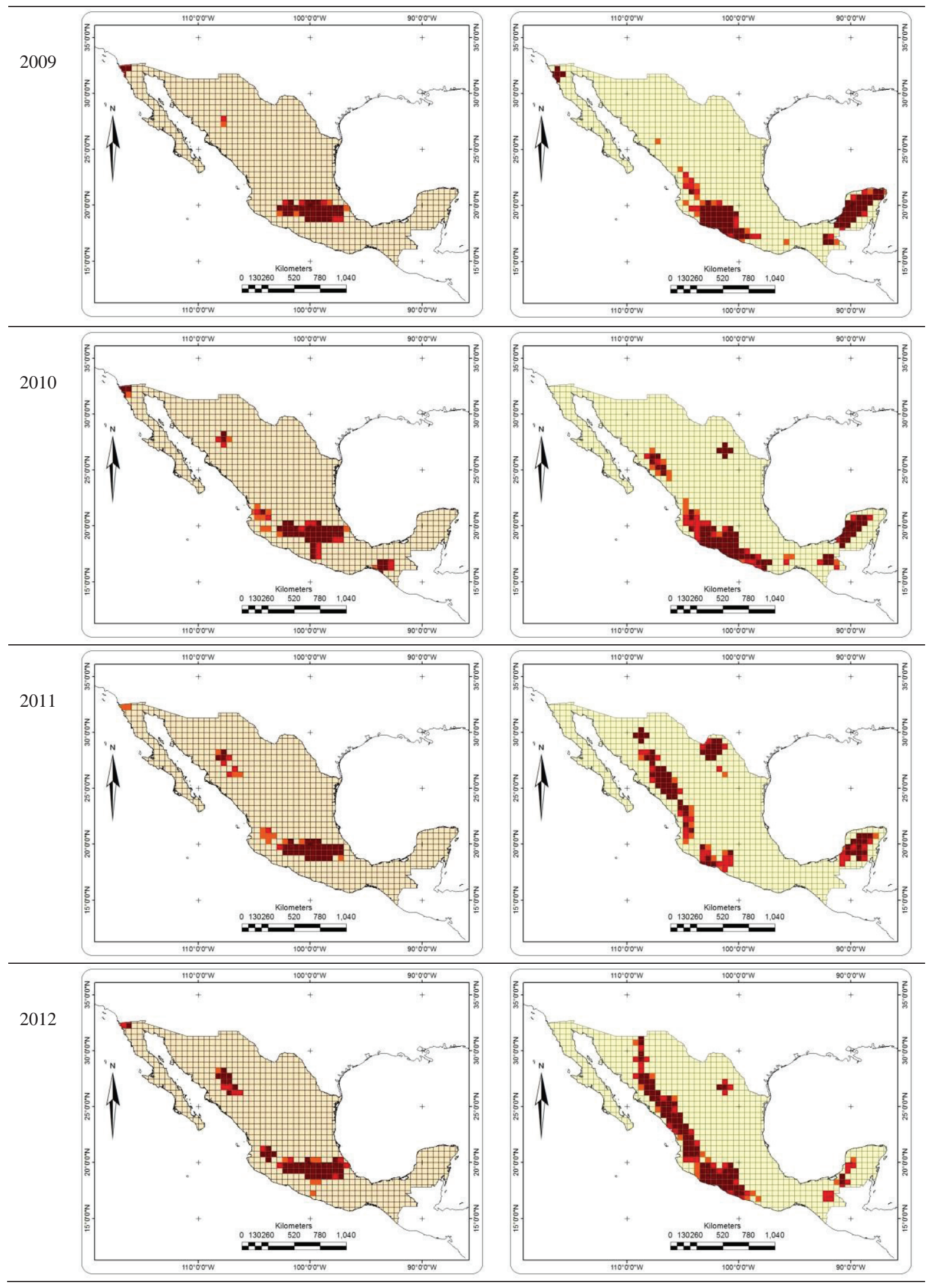

Continue 
Figure 5 Continued

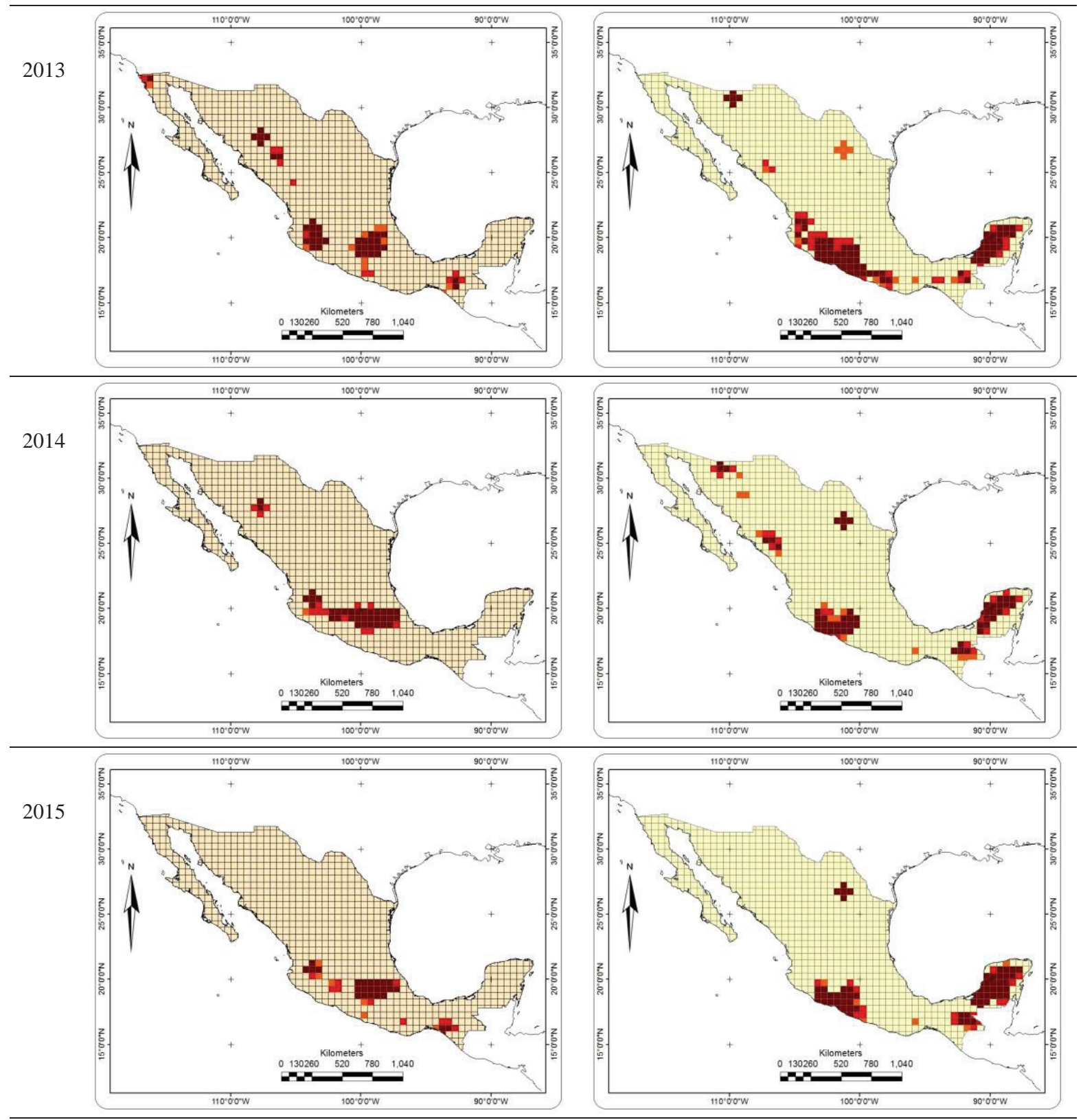

Legend

Gi Bin

\begin{tabular}{|l}
\hline Cold Spot - 99\% Confidence \\
Cold Spot - 95\% Confidence \\
Cold Spot - 90\% Confidence \\
Not Significant \\
Hot Spot - 90\% Confidence \\
Hot Spot - 95\% Confidence \\
\hline Hot Spot - 99\% Confidence
\end{tabular}

Figure 5. Annual spatial trend of forest fires in the two data sources A) CONAFOR, B) MODIS.

Tendencia espacial anual de incendios forestales en las dos bases de datos A) CONAFOR, B) MODIS. 


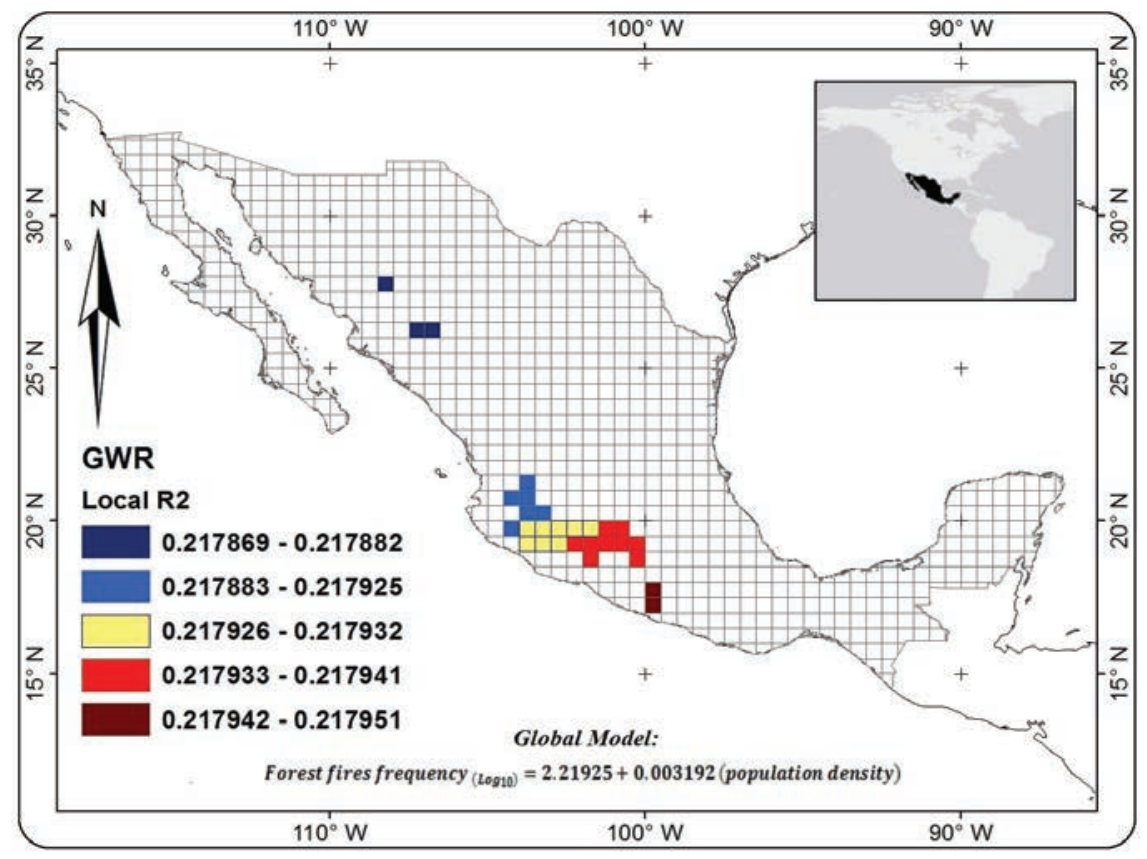

Figure 6. Local $R^{2}$ of GWR between fire frequency and population density.

$\mathrm{R}^{2}$ de la regresión geográficamente ponderada entre frecuencia de incendios y densidad de población.

\section{DISCUSSION}

Spatial trend. Many studies of forest fires have been conducted in Mexico over the past few years, but efforts to spatially characterize fire distribution in terms of spatial aggregation have been relatively scarce and limited to regional analyses (e.g., Ávila-Flores et al. 2010a, PerezVerdín et al. 2013). To date, no effort had been made to quantitatively compare the spatial characteristics of clustering at the national scale.

The study demonstrated that forest fires in Mexico showed a spatial clustering trend. To our knowledge, it is the first report that provides a complete quantitative spatial perspective of its occurrence using two data sources. This agrees with Yang et al. (2007), Ávila-Flores et al. (2010a), and Simental and Pompa (2016), who report forest fires as non-random events.

The G statistic test proved to be very helpful in the spatial analysis of forest fires. This quantitative tool is simple and statistically supported to determine the degree of clustering or hot spots (Pompa and Hernández 2012).

Areas with different rates of forest fire clustering were found in Mexico thanks to the G statistic. Special emphasis is given to areas with high clustering rates or hot spots (categories 1, 2 and 3, with reliability percentages of 90 , 95 and $99 \%$, respectively), since in those areas the occurrence of fires is very high. Therefore, their identification becomes a strategic factor for making timely decisions.

Thus, Ávila-Flores et al. (2010a) suggest the need to statistically explain this phenomenon through some spe- cific regression method, which allows finding explanatory variables of fire clustering. Also, Pompa and Hernández (2012) mention that further studies on forest fire risk should be complemented by additional information, such as fuel mapping, or even socio-economic information to determine a comprehensive risk index.

The first prerequisite is to find out the areas that continuously have these events. The hot spots generated here fulfill this need. The next step is to support the development of fire management programs from these geographic areas and to associate them with their explanatory variables: from biophysics (climate, fuels, topography, etc.) (Ávila-Flores et al. 2010b) to socioeconomic processes (land tenure, education, working conditions, etc.). The geographical representation of forest fires is the first step that enhances the study of this phenomenon. For example, in Chile, most of them were strongly associated with the road network and anthropogenic data (Díaz-Hormazábal and González 2016). This may be consistent with our results (figure 5). Particularly, focus should go to the area at the western end of the Eje Neovolcánico that shows a larger clustering value, compared to the area in Sierra Madre del Sur, Península de Yucatán, and Sierra Madre Occidental. This knowledge allows its use as a support tool to outline strategic policies in terms of priority.

We focused our study on spatial distribution of forest fires; however, there are many drivers of fire ignitions (e.g., type of vegetation burnt, fire regime, anthropogenic influences, type of land use activities, among others) that are beyond the scope of this work. Fire ignitions have been 
reported to have specific spatial occurrence patterns (e.g., Prestemon and Butry 2005, McRae and Sharples 2015), which result from different environmental or socioeconomic factors (Yang et al. 2007, Pérez-Verdín et al. 2013, Salvati et al. 2014). Some studies have shown that spatial patterns of fire hotspots are related to their causes. For example, studies by Prestemon and Butry (2005) and Genton et al. (2006) found that fires caused by arsonists were more spatially clustered than those caused by other types of ignitions. For Salvati et al. (2014), in a study conducted in the Mediterranean, the spatial distribution of fire occurs according to socio-economic variables. Here, our exploratory analysis showed the fires frequency is associated mainly with anthropogenic causes (figure 6).

Since analysis of fire regimes are not easy to establish, it is necessary to develop more detailed spatial models that provide information on the social and biophysical interactions that affect the occurrence of fires. It is important to note that the spatial scale aspect plays an important role (Parisien et al. 2006). In the same way, our results show the existence of different spatial patterns as a function of local factors.

Integration of CONAFOR-MODIS data sources. With the spatial correlation of both coverages, it was possible to determine the similarities and inconclusive discrepancies between the databases (figure 5). It is peculiar, for example, that the main fire area of the country (Eje Neovolcánico) (Rodríguez 2001) was only relevant for the CONAFOR database. This could mean inefficiencies in fire-fighting on both bases. A more frequent comparison of both datasets (NASA-CONAFOR) is recommended so that they are standardized. In theory, if both were efficient by themselves, they would have to be similar. In this way, both sources of information complement each other. Their union is strengthened in their scopes since according to NASA (2016), a comprehensive forest fire management system requires sufficiently precise and updated databases.

Current research on forest fires is focusing worldwide on remote sensing (Boschetti et al. 2015, Tarimo et al. 2015). The advantage of monitoring updated and easily accessible data is an advantage. However, there must be caution with the data source, as this can lead to over detection of fires since observations can be made several times in a day (Parajuli et al. 2015). In a study by Jin et al. (2003), many fires were recorded twice. MODIS has the advantage of detecting fires at more precise times (Reeves et al. 2006), as well as making considerable improvements in spatial resolution (Stocks et al. 2001). However, Schroeder et al. (2010) validated fires, finding a high omission error. This has been reported in other studies (Roy and Boschetti 2009, Boschetti et al. 2015), which limit the effectiveness of these products to larger scales when finer information and resolution -than the one available in the public domain- is required. The MODIS sensor recognizes more hot spots and usually overestimates the actual fire data, since this system recognizes any infrared radiation emitted by the fire regardless of where it is located, like for example, recording fires in non-forest areas (brick kilns, sawdust burners, agricultural fires near forest areas, etc.). Due to this, special emphasis is placed on the importance of the geoprocessing analysis with the land use coverage conducted by the CONABIO (2016). This allowed non-vegetated surface fires (on bare soil cover, urban areas, agricultural areas, water bodies, etc.) to be discarded. This reduced the number of fires by $44 \%$ compared to the initial analysis.

The main errors of the data collected on field are related to omissions of location and characteristics, provision of resources for detection, access difficulties, costs and time. CONAFOR records are exceeded by $87.83 \%$ by the MODIS sensor. However, these records foster a starting point generated by local knowledge. Since satellite detection is limited to bare soil emitting heat, shadows and cloudiness (Tarimo et al. 2015), it can lead to confusions. For this reason, the combination of both techniques strengthens their weaknesses and complements their advantages.

Proper fire management requires knowledge on fire nature and dynamics (Antunes et al. 2014). Therefore, the assessment of forest fires through hot spots is of particular importance in describing regional trends and developing mitigation strategies. Results show that $21 \%$ of the forest area is being affected by fires. Some areas have higher intensities than others, which can be related to their coverage, fuels and climate conditions at the time of the fire, month in which the fire occurred, topographic complex or socio-economic data.

The number of annual fires manifests randomly, noting that the different conditions that affect the number of fires in a particular year do not affect the number of fires in the following year. This phenomenon is similar to precipitations. One year may be humid and the next one dry (Perez-Verdín et al. 2013). In general terms, both databases annually showed the same spatial behavior along the Mexican territory. This agrees with Velasco (2016) in the study on decadal variations of forest fires in Mexico, which shows a high incidence in Sierra Madre Occidental, Sierra Madre Oriental, and the Neovolcanic Axis. However, in a comparative way, these two data sources show spatial dissimilarities whose causes may motivate further research.

\section{CONCLUSIONS}

This study used two databases to evaluate the spatial distribution of forest fires in Mexico. One used an on-field information (CONAFOR) and the other was based on remote sensing (MODIS). The spatial analysis for the two fire databases was done through the Getis-Ord G-statistic test. This statistical tool identified the different clustering trends of spot densities and thus was able to verify if fires were clustered into units with high or low values. Results indicate that the hypothesis of complete spatial randomness in both sources of information is rejected. Forest 
fires follow a high clustering pattern, which rejects our hypothesis that fires occur by chance. The two analyzed sources showed high clustering values in different areas.

The use of remote sensing (e.g. MODIS) and field data are suitable tools for studying phenomena such as the spatial distribution of forest fires. While they rely on different methodologies, they can be used as supplementary sources to study fire occurrence. With the spatial correlation in both sources, it was possible to determine their similarities and inconclusive discrepancies. The results of this study can help to better design a risk index and strategic policies. Though the frequency seems to be associated with climatic and anthropogenic causes, it is necessary to use more detailed and almost real-time spatial information.

\section{ACKNOWLEDGEMENTS}

We would like to thank CONAFOR for providing field data. The authors are grateful to the editors and anonymous reviewers for their useful comments and suggestions.

\section{REFERENCES}

Antunes G, O Abilio, R Fontes, R Trancoso, R Figueredo, C McManus. 2014. Spatial patterns of fire recurrence using remote sensing and GIS in the Brazilian Savanna: Serra do Tombador Nature Reserve, Brazil. Remote Sensing 6: 98739894. DOI: $10.3390 /$ rs6109873

Ávila-Flores D, M Pompa, E Vargas. 2010a. Análisis espacial de la ocurrencia de incendios forestales en el estado de Durango. Revista Chapingo Serie Ciencias Forestales y del Ambiente 16(2): 253-260.

Ávila-Flores D, M Pompa, X Antonio, DA Rodríguez, E Vargas, J Santillan. 2010b. Driving factors for forest fire occurrence in Durango State of Mexico: A geospatial Fire ignition trends in Durango, México perspective. Chinese Geographical Science 20(6): 491-497.

Boschetti L, P Roy, O Justice, L Humber. 2015. MODIS-Landsat fusion for large area $30 \mathrm{~m}$ burned area mapping. Remote Sensing Environmental 161:27-42. DOI: 10.1016/j. rse.2015.01.022.

Brundson C, A Fotheringham, M Charlton. 1996. Geographically weighted regression: a method for exploring spatial nonstationarity. Geographical Analysis 28(4):281-298.

Cartus O, J Kellndorfer, W Walker, C Franco, J Bishop, L Santos, J Fuentes. 2014. A National, Detailed Map of Forest Aboveground Carbon Stocks in Mexico. Remote Sensing 6: 5559-5588.

CONABIO (Comisión Nacional para el Conocimiento y Uso de la Biodiversidad, MX). 2016. Cobertura del suelo de México, Serie V. Catálogo de metadatos geográficos. Consultado 10 dic. 2016. Disponible en http://www.conabio.gob.mx/ informacion/gis/

CONAFOR (Comisión Nacional Forestal, MX). 2016. Reporte semanal de resultados de incendios forestales 2016. Programa Nacional de Prevención de Incendios Forestales. Del 01 de enero al 25 de agosto del 2016.

Díaz-Hormazábal I, M González. 2016. Análisis espaciotemporal de incendios forestales en la región del Maule,
Chile. Bosque 37(1): 147-158. DOI: 10.4067/S071792002016000100014

ESRI (Environmental Systems Research Institute, US). 2010. ArcGIS, software GIS. Version 10.0.

Genton MG, D Butry, M Gumpertz, J Prestemon. 2006. Spatiotemporal analysis of wildfire ignitions in the St Johns River Water Management District, Florida. International Journal of Wildland Fire 15:87-97.

Jin Y, B Schaaf, F Gao, X Li, H Strahler, W Lucht, S Liang. 2003. Consistency of MODIS surface bidirectional reflectance distribution function and albedo retrievals: 1. Algorithm performance. Journal of Geophysical Research: Atmospheres 108: 2-2.

McRae R, J Sharples. 2015. Assessing mitigation of the risk from extreme wildfires using MODIS hotspot data. In International Congress on Modelling and Simulation, Gold Coast, Australia. 29 November to 4 December 2015. www. mssanz.org.au/modsim2015. p. 250-256.

NASA (National Aeronautics and Space Administration, US). 2016. Earth data, active fire data. Consultado 15 sep. 2016. Disponible en https://earthdata.nasa.gov

Ord JK, A Getis. 1992. The analysis of spatial association by use of distance statistics. Geographical Analysis 24(3): 189-206.

Parajuli A, B Chand, B Rayamajhi, S Paudel. 2015. Spatial and temporal distribution of forest fires in Nepal. XIV World Forestry Congress, Durban, South Africa, 7-11 September 2015.

Parisien MA, V Peters, Y Wang, J Little, E Bosch, B Stocks. 2006. Spatial patterns of forest fires in Canada, 1980-1999. International Journal of Wildland Fire 15(3): 361-374.

Pérez-Verdín G, M Márquez-Linares, A Cortés-Ortiz, M Salmeron-Macías. 2013. Análisis espacio-temporal de la ocurrencia de incendios forestales en Durango, México. Madera y Bosques 19(2):37-58.

Pompa GM, P Hernández. 2012. Determinación de la tendencia espacial de los puntos de calor como estrategia para monitorear los incendios forestales en Durango, México. Bosque 33(1): 63-68.

Prestemon JP, T Butry. 2005. Time to burn: modeling wildland arson as an autoregressive crime function. American Journal of Agricultural Economics 87(3): 756-770.

Reeves M, C Zhao, W Running. 2006. Applying improved estimates of MODIS Productivity to characterize grassland vegetation dynamics. Rangeland Ecology \& Management 59:1-10.

Rodríguez DA. 2001. La ecología del fuego en el ecosistema de Pinus hartwegii. Revista Chapingo Serie Ciencias Forestales y del Ambiente 7(2): 145-151.

Roy DP, L Boschetti. 2009. Southern Africa validation of the MODIS, L3JRC, and GlobCarbon burned-area products. IEEE Transactions on Geoscience and Remote sensing 47(4):1032-1044. doi: 10.1109/TGRS.2008.2009000.

Salvati L, A Ferrara, M Carlucci. 2014. Understanding the Spatial Distribution of Forest Fires in a Growing Urban Region: Socioeconomic Indicators Tell You More. Modern Economy 5: 211-218. doi: 10.4236/me.2014.53022.

Schroeder W, I Csiszar, L Giglio, C Schmidt. 2010. On the use of fire radiative power, area, and temperature estimates to characterize biomass burning via moderate to coarse spatial resolution remote sensing data in the Brazilian Amazon. Journal Geophysical Research Atmosphere 115: D21121 doi: 10.1029/2009JD013769. 
Simental AJ, M Pompa. 2016. Incendios forestales: autocorrelación espacial de topografía y temporalidad. Ciencia UANL 19 (77): 41-45.

Stocks BJ, G Goldammer, H Frost, D Cahoon. 2001. Towards the Development of an Informed Global Policy on Vegetation Fires: What Role for Remote Sensing? In Frank J, G Goldammer, O Justice eds. Global and Regional Vegetation Fire Monitoring from Space. Hague, Netherlands. SPB Academic Publishing. p. 35-46.

Tarimo B, O Dick, T Gobakken, O Totland. 2015. Spatial distribution of temporal dynamics in anthropogenic fires in miombo savanna woodlands of Tanzania. Carbon Balance Manage 10:18. DOI: 10.1186/s13021-015-0029-2.

UEA (University of East Anglia, UK). 2016. Climatic Research Unit. Consulted 10 ago. 2016. Available in http://www.cru. uea.ac.uk/data $\% 20$ cited\#gsc.tab=0\&gsc.q=www.cru.uea. ac.uk\%20data $\% 2520$ cited\&gsc.sort

Velasco HG. 2016. Mexican forest fires and their decadal variations. Advances in Space Research 58: 2104-2115.

Yang J, H Hong-s, S Stephen-r, J Gustafson. 2007. Spatial patterns of modern period human-caused fire occurrence in the Missouri Ozark highlands. Forest Science 53(1): 1-15.

Recibido: 03.07.17

Aceptado: 16.10.17 